Contents available at: Sri Lanka Journals Online

\title{
Spatial Integration of Vegetable Markets of Sri Lanka during COVID-19 Pandemic
}

\author{
D. M. N. J. Kumari ${ }^{*}$, J. Weerahewa² ${ }^{2}$ and D. Hemachandra ${ }^{2}$ \\ ${ }^{1}$ Postgraduate Institute of Agriculture, University of Peradeniya, Peradeniya, 20400, Sri Lanka \\ ${ }^{2}$ Department of Agricultural Economics and Business Management, University of Peradeniya, Peradeniya, 20400, Sri \\ Lanka
}

\section{ARTICLE INFO}

\section{Article history:}

Received: 11 July 2021

Revised version received: 22 October 2021

Accepted: 23 October 2021

Available online: 01 January 2022

Keywords:

Augmented Dickey Fuller test COVID-19

Engle-granger co-integration

Market integration

Vegetables

\section{Citation:}

Kumari, D.M.N.J., Weerahewa, J. and Hemachandra, D. (2022). Spatial integration of vegetable markets of Sri Lanka during Covid-19 pandemic. Tropical Agricultural Research, 33(1): 92101.

DOI: http://doi.org/10.4038/tar.v33i1.8538

Kumari, D.M.N.J.

https://orcid.org/0000-0002-4951-5078

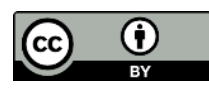

\section{ABSTRACT}

The majority of the vegetables moving through traditional supply chains pass via Dambulla Dedicated Economic Centre (DDEC), which is the main wholesale market in Sri Lanka, to the regional markets. With the COVID-19 pandemic, the Sri Lankan government implemented several measures to keep vegetable markets of the country integrated. The objective of this study was to examine the degree of market integration of nine regional wholesale vegetable markets with DDEC in Sri Lanka during the COVID-19 pandemic. Pairwise comparisons between vegetable prices at DDEC and regional markets were done using EngleGranger Co-integration test to achieve this objective. The analysis was carried out in the first differenced form, which conformed to the Augmented Dickey-Fuller (ADF) tests of stationarity. Short-run price disequilibrium was tested using Vector Auto-Regression Model (VAR) and Vector Error Correction Model (VECM). Weekly wholesale prices of beans, carrot, tomato, and brinjal markets during 2018-2021 were used for the analysis. The results revealed that only bean markets in Dehiaththakandiya, Thambuttegama, Nuwara Eliya, Meegoda, and Colombo wholesale vegetable markets depicted cointegrated behaviour with DDEC during the COVID-19 period. None of the other vegetable markets were integrated spatially with DDEC during the COVID-19 period. Before the pandemic, except in Ampara, Colombo and Dehiaththakandiya regional markets, all the other regional markets for beans, carrot, tomato, and brinjal were spatially integrated with DDEC either long run or short run. In conclusion, despite various government interventions to keep the vegetable market channels smoothly and consistently, the COVID-19 has negatively affected on price transmission of the vegetable marketing system of the country.

\footnotetext{
*Corresponding author: nimesha.dmjeewanthi@gmail.com
} 


\section{INTRODUCTION}

Agricultural markets play an essential role in economic development, especially income generation, alleviation of poverty, and ensuring food security in rural areas. Wholesale vegetable markets are places where primary producers, collectors, commission agents, vendors, and consumers meet each other to make market transactions. They serve as key distribution hubs for most of the agri-food supply chains. Proper functioning of agricultural markets is vital for increasing farmer income, reducing food prices, minimizing post-harvest losses, reducing health risks, etc. The performance of agricultural markets depends on supply and demand dynamics, which can change due to weather, political environment, pest $\&$ disease incidences, and many other factors. During the COVID-19 pandemic, agricultural markets were heavily disrupted. The Dambulla Dedicated Economic Centre (DDEC), the leading wholesale vegetable market of Sri Lanka, was disrupted owing to the health regulations imposed by the government of Sri Lanka during the pandemic. DDEC is the primary assembly and distribution point for vegetables in the country and is a distribution hub in the vegetable supply chain. Approximately $70 \%$ of the vegetables moving through traditional supply chains pass via the DDEC, and the price changes in DDEC are directly transmitted to other regional markets (Perera, 2011). To mitigate disruptions in the food-supply chains caused by the health regulations imposed to combat COVID-19, the government took immediate actions to purchase vegetables from vulnerable farmers and allowed vegetable transportation all over the country (Rajeevan, 2021; IPS, 2021), intending to keep the vegetable markets integrated.

The degree to which a market hub is integrated with other spatial markets can be determined by examining the co-movement of prices in different markets. This is termed spatial integration (Faminow, 1990), and it enables to determine whether transmission of price signals and information across spatially separated markets are smooth (Goletti et al., 1995; Alexander and Wyeth, 1994). If price changes in one market are fully reflected in an alternative market, these markets are considered spatially integrated. In Sri Lanka, many research studies have been conducted on price linkages and market integration in the rice market, milk market, fish market, etc. A study conducted by Jayasinghe-Mudalige (2006) on spatial integration of regional rice markets in Sri Lanka suggested that the prices in several selected rice markets were highly integrated both in the short-run and long-run perspectives. Another study by Thamiem et al. (2010), on market integration of Sri Lankan milk market revealed that the prices of central milk markets in the country significantly influence the price levels in the neighbouring regional markets while transmitting to the regional markets at a degree of 0.24 to 1.02 within a geographical region. De Silva (2006) examined price efficiency in tuna fish marketing in Sri Lanka. Findings revealed that all the tuna fish markets were integrated and showed short-run stability and were somewhat competitive. To the best of the authors' knowledge, only Sandaruwani (2018) examined the spatial integration of vegetable markets in Sri Lanka. Her findings showed that only six regional markets for green chili, out of the 25 markets examined, were integrated with DDEC. This study examined the degree of market integration between selected regional vegetable wholesale markets and DDEC during COVID-19. It compared the degree of market integration during COVID-19 with that of the pre-COVID-19 period in beans, carrot, tomato, and brinjal markets.

\section{METHODOLOGY}

\section{Correlation matrix}

A correlation matrix is a table showing correlation coefficients between sets of variables. Each random variable $\left(\mathrm{X}_{\mathrm{i}}\right)$ in the table is correlated with each other in the table $\left(\mathrm{X}_{\mathrm{j}}\right)$. This allows to see which pairs are highly correlated with each other. The correlation coefficients among market pairs are calculated to show the associations.

\section{Model}

The following empirical model was used for evaluating spatial price linkages (Goodwin and Schroeder (1991).

$$
P_{t}^{1}=\beta_{0}+P_{t}^{2} \beta_{1}+v_{t}
$$

$\mathrm{P}^{1}{ }_{t}$ and $\mathrm{P}^{2}$ represent commodity prices of a homogenous good in two alternative regional markets at time $t, \beta_{0}$ and $\beta_{1}$ are parameters, and $v_{t}$ is the error term. If two markets are perfectly spatially integrated, then $\beta_{1}=1$. On such occasions, price changes in one market are fully reflected in the other market. When $\beta_{1} \neq 1\left(\beta_{1}<1\right.$ or $\left.\beta_{1}>1\right)$, then degree of integration is evaluated by investigating how far is the deviation of $\beta_{1}$ from unity.

\section{Estimation method and unit root test}

Method for estimating Equation (1) depends on the time series properties of commodity prices in each 
location. This study used Engle and Granger cointegration method. For any analysis of time series modelling, the unit root test is a preliminary step to determine whether the series is stationary or not. Time series variables may contain a trend, a cycle, a seasonal and an unpredictable component. A non-stationary time series of order $d$ can become stationary after differencing $d$ times where $d$ is the order of integration and is said to be integrated of $\mathrm{I}(d)$. The order of integration is the number of unit roots contained in the series. To analyse the time series properties and test for the unit root, the study applied the Augmented Dickey-Fuller (ADF) test (Dickey and Fuller 1979). The null hypothesis for the ADF test is that the series has a unit root against the alternative that the series does not have a unit root. Non-stationary time series variables may possess long run equilibrium relationships and thus tend to move together in the long run, that is, they are said to be cointegrated (Engle and Granger 1987). Two or more non-stationary variables are considered cointegrated if one or more linear combinations of the variables are stationary. The Engle and Granger (1987) cointegration test provides a framework for estimating and testing long run equilibrium relationships between non-stationary integrated variables.

\section{Augmented Dickey-Fuller (ADF) test}

To analyse the properties of the time series data and test for the unit root, the study applied the ADF test (Dickey and Fuller 1979). The null hypothesis for the ADF test is that the series has a unit root against the alternative that the series does not have a unit root.

$\mathrm{H}_{0}$ : The time series has a unit root/ time series is showing non-stationarity

$\mathrm{H}_{1}$ : The series does not have a unit root/ time series is showing stationarity

As described in Hamilton (1994), the ADF test is carried out by estimating the following equation:

$$
\begin{gathered}
P_{t}=\mu+\varphi P_{t-1}+\beta_{1} \Delta P_{t-1}+\beta_{2} \Delta P_{t}+\cdots+ \\
\beta_{k-1} \Delta P_{t-k+1}+\varepsilon_{t}
\end{gathered}
$$

where $\mathrm{P}_{\mathrm{t}}$ is price at time $\mathrm{t}$ at a location, $\Delta \mathrm{P}_{\mathrm{t}}$ represents change in the price and is equal to $\left(\mathrm{P}_{\mathrm{t}}-\right.$ $\left.\mathrm{P}_{\mathrm{t}-1}\right), \mu, \varphi, \beta_{1}, \beta_{2}, \beta_{k-1}$ are parameters, $\mathrm{k}$ is the order of autoregressive model, and $\varepsilon_{\mathrm{t}}$ is the error term. Using the ADF test, we test the null hypothesis that $\mu=0$ and $\varphi=1$. Under the null hypothesis, Equation (2) is a unit root autoregressive model with no drift, and the time series is nonstationary.

\section{Engle and Granger cointegration test}

Non-stationary time series variables may possess long run equilibrium relationships and thus tend to move together in the long run, that is, they are said to be cointegrated (Engle and Granger 1987). The Engle and Granger (1987) cointegration test provides a framework for estimating and testing for long run equilibrium relationships between non-stationary integrated variables.

$\mathrm{H}_{0}$ : There is no cointegration between DDEC and other markets

$\mathrm{H}_{1}$ : There is cointegration between DDEC and other markets

Engle-Granger methodology follows two-step estimations. The first step generates the residuals, and the second step uses generated residuals to estimate a regression of first differenced residuals on lagged residuals. Hence, any possible error from the first step will be carried into second step (Bilgili, 1998). If the market price data are not showing cointegration in long-run, a Vector Autoregression model (VAR) or Vector Error Correction Model (VECM) is used to see whether there are short-run price equilibriums among the market pairs.

\section{Data}

The degree of market integration was analysed using the data collected from the secondary data base from Hector Kobbekaduwa Agrarian Research and Training Institute (HARTI) on selected regional vegetable markets. For this study, 10 wholesale markets; DDEC, Colombo, Thambuttegama, Ampara, Meegoda, Keppetipola, Nuwara Eliya, Dehiaththakandiya, Badulla and Galle, were selected as these were large primary distributing centres of vegetables in the country (Figure 1). Among them, Thambuttegama, DDEC, Meegoda, Keppetipola and Nuwara Eliya were Dedicated Economic Centres. The wholesale prices of beans, tomatoes, carrots and brinjals, were converted into real prices using the Colombo Consumer Price Index (CPI, Base: $2010=100)$. The study used weekly wholesale real prices of four vegetables in the COVID-19 period. The study considered the period between 2020 June to 2021 June as the COVID-19 pandemic period. For the comparison purpose, 2018 and 2019 years were considered as the pre-COVID-19 period. All the time series price data were transformed into natural log-form to eliminate variations in movement due to level differences and to avoid counterfeit relationships. Data on price variation of selected vegetables over the time; before and during COVID-19, were also collected. 


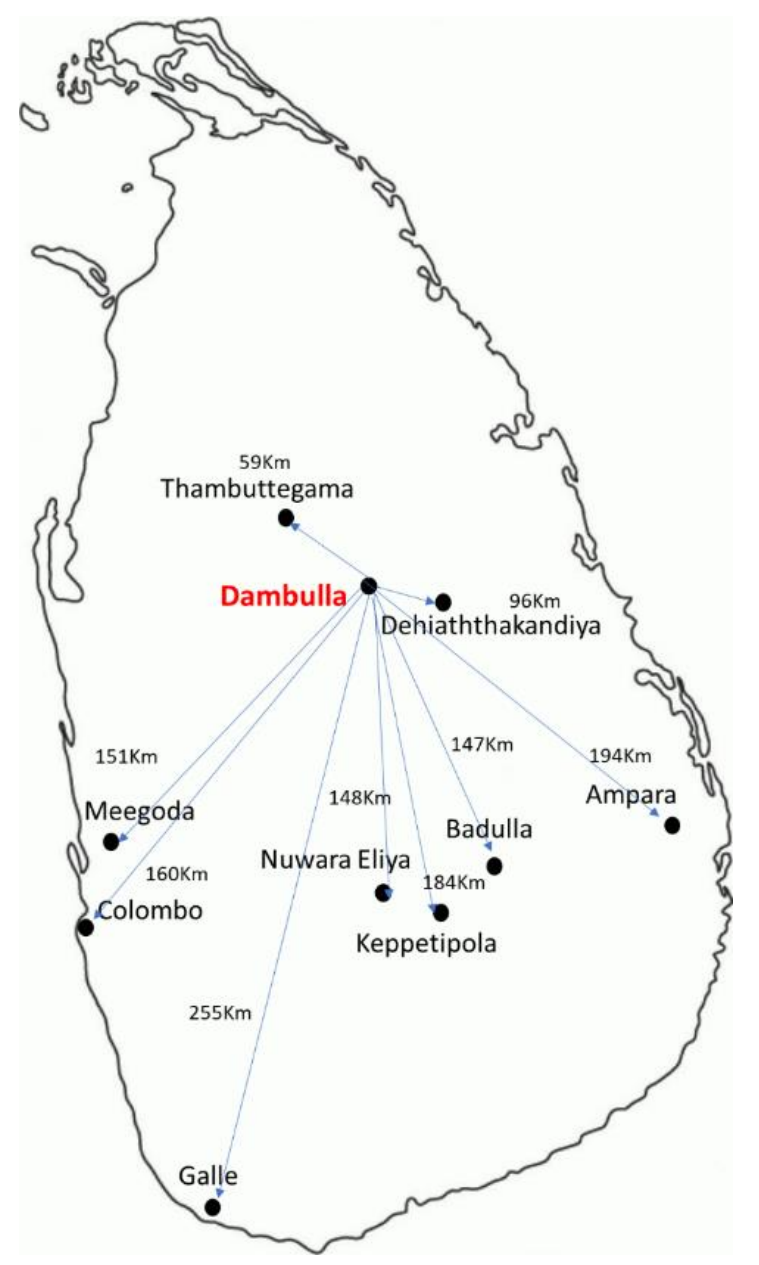

Figure 1. Selected regional markets and the distances from DDEC

\section{RESULTS AND DISCUSSION}

\section{Test results for the COVID-19 period (June 2020 to June 2021)}

\section{Correlation matrix for the prices of vegetable markets}

Correlation coefficients from a correlation matrix provide a general understanding of which pairs are highly correlated with each other. Figure 3 shows the correlation results of the wholesale vegetable markets of Sri Lanka for the COVID-19 period considered in the study. All the correlation matrices show that most of the selected vegetable markets do not show strong and positive correlations with DDEC during COVID-19 period. However, correlation coefficients for the price of beans in Nuwara Eliya, Colombo and Meegoda markets, and tomato in Thambuttegama, Colombo,
Meegoda and Nuwara Eliya markets were greater than 0.80 indicating strong and positive relationships between prices in these markets (Figure 2).

\section{Augmented Dickey-Fuller (ADF)}

Unit roots of all wholesale price series of selected vegetables; beans, carrots, tomatoes, brinjals were tested using the ADF procedure before a cointegration analysis or autoregression.

The results from the ADF tests for the four types of vegetables for the period of COVID-19 are presented in Supplementary Tables S1 - S2. Almost all the vegetables showed non-stationarity in prices at level I (0) and when the first differenced series were tested, all of the ADF statistics became statistically significant, indicating that the series were stationary after first differencing. This implies that the all price level series were I (1). 


\begin{tabular}{|c|c|c|c|c|c|c|c|c|c|c|}
\hline & \multicolumn{10}{|c|}{ Beans } \\
\hline & Colon & Damb & Thaml & Ampa & Meegı & Keppe & Nuwa & Dehia' & Badull & ialle \\
\hline Colombo & 1 & & & & & & & & & \\
\hline Dambulla & 0.81 & 1 & & & & & & & & \\
\hline Thambutt $\epsilon$ & 0.84 & 0.73 & 1 & & & & & & & \\
\hline Ampara & 0.35 & 0.14 & 0.13 & 1 & & & & & & \\
\hline Meegoda & 0.88 & 0.82 & 0.90 & 0.25 & 1 & & & & & \\
\hline Keppetipol & -0.52 & -0.41 & -0.31 & -0.06 & -0.40 & 1 & & & & \\
\hline Nuwara el & 0.82 & 0.80 & 0.77 & 0.32 & 0.88 & -0.45 & 1 & & & \\
\hline Dehiathth & 0.46 & 0.39 & 0.33 & 0.14 & 0.46 & -0.11 & 0.47 & 1 & & \\
\hline Badulla & 0.50 & 0.41 & 0.35 & 0.62 & 0.47 & 0.10 & 0.46 & 0.66 & 1 & \\
\hline Galle & 0.52 & 0.45 & 0.44 & 0.37 & 0.52 & -0.19 & 0.45 & 0.36 & 0.57 & 1 \\
\hline
\end{tabular}

Tomato

\begin{tabular}{|c|c|c|c|c|c|c|c|c|c|c|}
\hline & \multicolumn{10}{|c|}{ Colon Damb Thaml Ampa Meegı Keppe Nuwa Dehia Badull Galle } \\
\hline Colombo & 1 & & & & & & & & & \\
\hline Dambulla & 0.90 & 1 & & & & & & & & \\
\hline Thambutt $\epsilon$ & 0.95 & 0.90 & 1 & & & & & & & \\
\hline Ampara & 0.86 & 0.69 & 0.80 & 1 & & & & & & \\
\hline Meegoda & 0.96 & 0.91 & 0.99 & 0.82 & 1 & & & & & \\
\hline Keppetipol & -0.04 & -0.22 & -0.12 & 0.19 & -0.15 & 1 & & & & \\
\hline Nuwara el & 0.94 & 0.90 & 0.97 & 0.82 & 0.97 & -0.17 & 1 & & & \\
\hline Dehiathth & 0.69 & 0.68 & 0.66 & 0.57 & 0.70 & -0.29 & 0.65 & 1 & & \\
\hline Badulla & 0.87 & 0.76 & 0.83 & 0.89 & 0.84 & 0.14 & 0.8 & 0.74 & 1 & \\
\hline Galle & 0.79 & 0.75 & 0.85 & 0.70 & 0.82 & -0.14 & 0.86 & 0.59 & 0.74 & 1 \\
\hline
\end{tabular}

\begin{tabular}{|c|c|c|c|c|c|c|c|c|c|c|}
\hline & \multicolumn{10}{|c|}{ Carrot } \\
\hline & \multicolumn{10}{|c|}{ Colom Dambı Thamk Ampar Meegc Keppet Nuwar Dehiat Badulli Galle } \\
\hline Colombo & 1 & & & & & & & & & \\
\hline Dambulla & 0.67 & 1 & & & & & & & & \\
\hline Thambutt€ & 0.70 & 0.67 & 1 & & & & & & & \\
\hline Ampara & 0.13 & 0.32 & 0.29 & 1 & & & & & & \\
\hline Meegoda & 0.80 & 0.71 & 0.77 & 0.11 & 1 & & & & & \\
\hline Keppetipol & 0.55 & 0.26 & 0.67 & 0.00 & 0.49 & 1 & & & & \\
\hline Nuwara eli & 0.61 & 0.42 & 0.72 & 0.46 & 0.67 & 0.66 & 1 & & & \\
\hline Dehiaththe & 0.60 & 0.27 & 0.72 & 0.12 & 0.85 & 0.41 & 0.32 & 1 & & \\
\hline Badulla & 0.63 & 0.54 & 0.79 & 0.22 & 0.78 & 0.59 & 0.58 & 0.72 & 1 & \\
\hline \multirow[t]{3}{*}{ Galle } & 0.74 & 0.76 & 0.79 & 0.55 & 0.78 & 0.46 & 0.78 & 0.41 & 0.71 & 1 \\
\hline & \multicolumn{10}{|c|}{ Brinjal } \\
\hline & Colom & Dambi & Thamk & Ampar & Meegc & Keppe1 & Vuwar L & Dehiat & Badull & \\
\hline Colombo & 1 & & & & & & & & & \\
\hline Dambulla & 0.79 & 1 & & & & & & & & \\
\hline Thambutt $\epsilon$ & 0.78 & 0.66 & 1 & & & & & & & \\
\hline Ampara & 0.73 & 0.44 & 0.59 & 1 & & & & & & \\
\hline Meegoda & 0.86 & 0.74 & 0.91 & 0.63 & 1 & & & & & \\
\hline Keppetipol & 0.32 & 0.23 & 0.54 & 0.38 & 0.49 & 1 & & & & \\
\hline Nuwara eli & 0.86 & 0.69 & 0.83 & 0.66 & 0.90 & 0.52 & 1 & & & \\
\hline Dehiathth & 0.41 & 0.34 & 0.22 & 0.04 & 0.25 & -0.12 & 0.34 & 1 & & \\
\hline Badulla & 0.82 & 0.64 & 0.60 & 0.69 & 0.75 & 0.45 & 0.81 & 0.50 & 1 & \\
\hline Galle & 0.71 & 0.58 & 0.58 & 0.63 & 0.73 & 0.29 & 0.69 & 0.21 & 0.66 & 1 \\
\hline
\end{tabular}

Figure 2: Correlation matrices for the vegetable markets (During COVID-19)

While the correlation was used to check for the linear relationship or linear interdependence between market pairs, the co-integration was used to check for the existence of a long-run relationship between market pairs.

\section{Cointegration test results}

Table 1 reports the Engle - Granger cointegration tests results for 2020 June-2021 June period (COVID-19 period for the study). Out of 36 market pairs, only one market pair (DDEC and
Dehiaththakandiya for beans) was statistically significant at $5 \%$ critical level $(97 \%$ of the markets were not cointegrated with DDEC prices). Except for Dehiaththakandiya bean prices, the test statistics could not reject the null hypothesis of no cointegration at $5 \%$ significance level, implying that DDEC wholesale prices and wholesale prices of other markets of vegetables are not cointegrated with each other during the COVID-19 pandemic. Prices at Dehiaththakandiya regional market are the only prices which are moving together with the prices of DDEC for beans in the long run.

Table 1: Engle-Granger cointegration testing results (COVID-19 period)

\begin{tabular}{lcccccccc} 
& \multicolumn{2}{c}{ Beans } & \multicolumn{2}{c}{ Carrot } & \multicolumn{2}{c}{ Tomato } & \multicolumn{2}{c}{ Brinjal } \\
\hline $\begin{array}{l}\text { Regional vegetable } \\
\text { market }\end{array}$ & $\begin{array}{c}\text { Test } \\
\text { Statistics }\end{array}$ & p Value & $\begin{array}{c}\text { Test } \\
\text { Statistic } \\
\mathrm{s}\end{array}$ & $\mathrm{p}$ Value & $\begin{array}{c}\text { Test } \\
\text { Statistics }\end{array}$ & p Value & $\begin{array}{c}\text { Test } \\
\text { Statistics }\end{array}$ & $\mathrm{p}$ Value \\
\hline Colombo & -1.79 & 0.4062 & -0.99 & 0.7562 & -1.92 & 0.3187 & -2.79 & 0.0596 \\
Thambuttegama & -1.96 & 0.3027 & -1.36 & 0.5990 & -2.18 & 0.2137 & -0.59 & 0.8727 \\
Ampara & -2.10 & 0.2437 & -2.21 & 0.2011 & -1.51 & 0.5242 & -0.30 & 0.9246 \\
Meegoda & -1.97 & 0.2971 & -2.27 & 0.1789 & -2.34 & 0.1590 & -2.36 & 0.1522 \\
Keppetipola & -1.54 & 0.5119 & -1.38 & 0.5901 & -0.85 & 0.8026 & -1.69 & 0.4345 \\
Nuwara Eliya & -0.66 & 0.8560 & -1.37 & 0.5961 & -2.39 & 0.1442 & -2.77 & 0.0617 \\
Dehiaththakandiya & -5.45 & $0.0000^{*}$ & 0.81 & 0.9919 & -0.14 & 0.9445 & -0.49 & 0.8926 \\
Badulla & -1.58 & 0.4911 & -0.82 & 0.8118 & -1.95 & 0.3063 & -1.98 & 0.2922 \\
Galle & -0.39 & 0.9111 & -0.12 & 0.9471 & 0.08 & 0.9650 & -1.75 & 0.4026 \\
\hline
\end{tabular}

*Values followed by same letters in a column are not significantly different at $\mathrm{p}<0.05$ 
Table 2: Results of the Vector Autoregression Model (VAR) (for COVID-19 period from June 2020 to June 2021)

\begin{tabular}{lcccccccc}
\hline \multirow{2}{*}{$\begin{array}{l}\text { Regional } \\
\text { vegetable market }\end{array}$} & \multicolumn{2}{c}{ Beans } & \multicolumn{2}{c}{ Carrot } & \multicolumn{2}{c}{ Tomato } & \multicolumn{2}{c}{ Brinjal } \\
\cline { 2 - 9 } & Coef. & p Value & coef. & p Value & coef. & p Value & Coef. & Value \\
\hline Colombo & 0.27 & $0.0000^{*}$ & -0.99 & 0.7562 & -1.93 & 0.3187 & -2.79 & 0.0596 \\
Thambuttegama & 0.99 & $0.0000^{*}$ & -1.37 & 0.5990 & -2.18 & 0.2137 & -0.59 & 0.8727 \\
Ampara & 0.15 & 0.1880 & -2.21 & 0.2011 & -1.52 & 0.5242 & -0.31 & 0.9246 \\
Meegoda & 0.36 & $0.0000^{*}$ & -2.28 & 0.1789 & -2.34 & 0.159 & -2.36 & 0.1522 \\
Keppetipola & 0.01 & 0.9130 & 1.38 & 0.5901 & -0.86 & 0.8026 & -1.69 & 0.4345 \\
Nuwara Eliya & 0.30 & $0.0000^{*}$ & -1.37 & 0.5961 & -2.39 & 0.1442 & -2.78 & 0.0617 \\
Dehiaththakandiya & -0.03 & 0.8510 & 0.81 & 0.9919 & -0.15 & 0.9445 & -0.50 & 0.8926 \\
Badulla & 0.01 & 0.9530 & -0.83 & 0.8118 & -1.96 & 0.3063 & -1.99 & 0.2922 \\
Galle & 0.17 & 0.3200 & -0.12 & 0.9471 & 0.08 & 0.965 & -1.76 & 0.4026 \\
\hline
\end{tabular}

* Values followed by same letters in a column are not significantly different at $\mathrm{p}<0.05$

Since most of the regional vegetable markets were not cointegrated with DDEC in the long-run, it was tested whether there are cointegrations among market pairs in short-run. In cases where the markets are not cointegrated with each other, Vector-Auto-Regression (VAR) model is used to test the short-run price equilibriums. Table 2 shows the VAR results of the period COVID-19 period considered for the study. The results revealed that for beans; Colombo, Thambuttegama, Meegoda and Nuwara Eliya markets were cointegrated with DDEC in the short run. None of the other markets were having a short run cointegration with DDEC prices.

The results of both Engle-Granger cointegration test and VAR exhibit that the existing few cointegration behaviours among regional markets are only for the bean prices. One possible reason for this behaviour may be the higher production of beans in areas such as Badulla, Dambulla and Welimada which are transported through wellestablished supply chains to main vegetable markets of the country during the pandemic. Another possible reason may be that compared to other vegetables selected in the study, beans are less perishable. Therefore, beans can be stored easier than tomatoes, carrots or brinjals. Vegetables piled up in most markets due to transport restrictions. Loads of vegetables perished due to delays in transport. However, for beans, the effect might be lower than others.

The possible reasons for all the other noncointegrated behaviour of the markets may be due to the supply and demand side interruptions occurred during the pandemic. Time to time DDEC and other regional markets were closed to curb the spread of COVID-19. According to the activities permitted based on alert level III by the Health Services Director General of Sri Lanka, the regional markets were allowed to reopen only with a maximum of $25 \%$ total customers that can be accommodated within the premises. On the other hand, the vegetable transporters were allowed to transport vegetables to different parts of the country. The movement of vegetable transporters while the DECs and other regional centres were at the minimal level of operations made the situation more complex. The vegetable farmers and vendors started selling and buying vegetables outside the DEC premises and road sides. Thus, the behaviour of regional wholesale vegetable markets including DDEC during COVID-19 pandemic created several challenges and hence regional vegetable markets were not cointegrated with DDEC.

\section{Test results of pre-COVID-19 period (2018 and 2019)}

The pre-COVID-19 period price movements among regional vegetable markets and DDEC were analysed using correlation matrix, Augmented Dickey fuller test, Engle-granger cointegration test and error correction model, to compare with the cointegrated behaviour of prices between markets during the pandemic

\section{Correlation matrix for the prices of vegetables markets}

To have a general understanding of which market pairs are highly correlated with each other, correlation coefficients were calculated. Figure 3 shows the correlation results of the selected 
Beans

\begin{tabular}{|c|c|c|c|c|c|c|c|c|c|c|}
\hline & Color & Damk & Tham & Ampa & Meeg & Kepp & Nuwé & Dehic & a Badı & ul Galle \\
\hline Colombo & 1 & & & & & & & & & \\
\hline Dambulla & 0.88 & 1 & & & & & & & & \\
\hline Thambutt $\epsilon$ & 0.84 & 0.84 & 1 & & & & & & & \\
\hline Ampara & 0.93 & 0.91 & 0.81 & 1 & & & & & & \\
\hline Meegoda & 0.92 & 0.90 & 0.88 & 0.92 & 1 & & & & & \\
\hline Keppetipol & 0.91 & 0.91 & 0.84 & 0.96 & 0.91 & 1 & & & & \\
\hline Nuwara el & 0.78 & 0.78 & 0.71 & 0.83 & 0.82 & 0.89 & 1 & & & \\
\hline Dehiaththa & 0.84 & 0.86 & 0.83 & 0.82 & 0.82 & 0.87 & 0.65 & 1 & & \\
\hline Badulla & 0.87 & 0.88 & 0.82 & 0.92 & 0.90 & 0.89 & 0.79 & 0.75 & & 1 \\
\hline Galle & 0.89 & 0.87 & 0.77 & 0.93 & 0.90 & 0.91 & 0.85 & 0.75 & $0.8 \varepsilon$ & 1 \\
\hline
\end{tabular}

Tomato

\begin{tabular}{|c|c|c|c|c|c|c|c|c|c|c|}
\hline & Color & Damk & Tham & Ampa & Meeg & Kepp & Nuwe & Dehiz & ia Badu & | Galle \\
\hline Colombo & 1 & & & & & & & & & \\
\hline Dambulla & 0.95 & 1 & & & & & & & & \\
\hline Thambutt $\epsilon$ & 0.92 & 0.95 & 1 & & & & & & & \\
\hline Ampara & 0.92 & 0.95 & 0.91 & 1 & & & & & & \\
\hline Meegoda & 0.93 & 0.97 & 0.94 & 0.94 & 1 & & & & & \\
\hline Keppetipol & 0.92 & 0.93 & 0.86 & 0.94 & 0.94 & 1 & & & & \\
\hline Nuwara el & 0.89 & 0.88 & 0.85 & 0.91 & 0.88 & 0.93 & 1 & & & \\
\hline Dehiathth & 0.91 & 0.94 & 0.92 & 0.95 & 0.92 & 0.75 & 0.87 & & 1 & \\
\hline Badulla & 0.92 & 0.95 & 0.90 & 0.93 & 0.93 & 0.91 & 0.89 & 0.90 & 0 & \\
\hline Galle & 0.94 & 0.95 & 0.88 & 0.95 & 0.95 & 0.90 & 0.91 & 0.91 & 10.95 & 1 \\
\hline
\end{tabular}

Carrot

\begin{tabular}{|c|c|c|c|c|c|c|c|c|c|c|c|}
\hline & \multicolumn{11}{|c|}{ Color Damk Tham Ampa Meę̧ Keppı Nuw` Dehic Badul Galle } \\
\hline Colombo & 1 & & & & & & & & & & \\
\hline Dambulla & 0.93 & 1 & & & & & & & & & \\
\hline Thambutt $\epsilon$ & 0.92 & 0.93 & 1 & & & & & & & & \\
\hline Ampara & 0.93 & 0.93 & 0.91 & 1 & & & & & & & \\
\hline Meegoda & 0.92 & 0.95 & 0.96 & 0.91 & 1 & & & & & & \\
\hline Keppetipol & 0.92 & 0.93 & 0.88 & 0.94 & 0.91 & 1 & & & & & \\
\hline Nuwara el & 0.90 & 0.91 & 0.92 & 0.91 & 0.93 & 0.89 & 1 & & & & \\
\hline Dehiathth & 0.85 & 0.82 & 0.90 & 0.89 & 0.85 & 0.70 & 0.87 & 1 & & & \\
\hline Badulla & 0.90 & 0.88 & 0.85 & 0.88 & 0.85 & 0.87 & 0.80 & 0.78 & & 1 & \\
\hline Galle & 0.95 & 0.92 & 0.91 & 0.95 & 0.92 & 0.90 & 0.92 & 0.84 & 0.88 & 38 & 1 \\
\hline & \multicolumn{11}{|c|}{ Brinjal } \\
\hline & \multicolumn{11}{|c|}{ Color Damk Tham Ampa Meę̧ Keppı Nuw` Dehic Badul Galle } \\
\hline Colombo & 1 & & & & & & & & & & \\
\hline Dambulla & 0.76 & 1 & & & & & & & & & \\
\hline Thambutt $\epsilon$ & 0.77 & 0.85 & 1 & & & & & & & & \\
\hline Ampara & 0.79 & 0.82 & 0.75 & 1 & & & & & & & \\
\hline Meegoda & 0.83 & 0.91 & 0.83 & 0.82 & 1 & & & & & & \\
\hline Keppetipol & 0.55 & 0.72 & 0.63 & 0.71 & 0.67 & 1 & & & & & \\
\hline Nuwara el & 0.84 & 0.90 & 0.83 & 0.84 & 0.89 & 0.73 & 1 & & & & \\
\hline Dehiathth & 0.69 & 0.79 & 0.77 & 0.75 & 0.73 & 0.62 & 0.79 & 1 & & & \\
\hline Badulla & 0.80 & 0.77 & 0.71 & 0.72 & 0.79 & 0.73 & 0.79 & 0.72 & & 1 & \\
\hline Galle & 0.86 & 0.78 & 0.74 & 0.81 & 0.84 & 0.66 & 0.81 & 0.64 & $+0.7 \varepsilon$ & 78 & 1 \\
\hline
\end{tabular}

Figure 3: Correlation matrices for the vegetable markets in pre-COVID-19 period

wholesale vegetable markets for the period of 2018.and 2019 (pre-COVID-19 period). All the correlation matrices show that each of the selected vegetable markets exhibit strong and positive correlations with the prices at DDEC. Correlation coefficients of all the market pairs for beans, carrot, brinjal and tomato were more than 0.7 , implying that they are having strong and positive relationships with DDEC prices before COVID-19.

Even though the correlation coeffects exhibit linear relationship or linear interdependence between market pairs, co-integration among market pairs was also used to check for the existence of a longrun relationships.

\section{Cointegration test results}

Unit roots of all wholesale price series of selected vegetables; beans, carrots, tomatoes, brinjals were tested using the ADF procedure before a cointegration analysis or autoregression. The results from the ADF tests for the four types of vegetables for the pre-COVID-19 period are presented in Supplementary Tables S3 - S6.

Since the price series are integrated of order I (1) and their corresponding first differenced series are $\mathrm{I}(0)$, the study tested whether the price series in markets were cointegrated with the Dambulla Dedicated Economic Centre's wholesale prices using the Engle and Granger (1987) approach. Table 3 below reports the Engle - Granger cointegration tests results. The analysis was carried out for each market pair with each pair containing DDEC as the hub. Therefore, the cointegration was checked between the regional markets and DDEC.

When Ampara market is tested against DDEC, the ADF statistics of the residuals were not significant at 5\% critical level for beans, carrot, and tomato. Keppetipola market also showed higher ADF values - and are not significant at 5\% level for beans and carrots. When the regional market in Galle is tested with the DDEC, higher ADF values were observed in carrots, tomatoes and brinjals. Therefore, for the above three market pairs, Ampara, Keppetipola and Galle, the null hypothesis of the Engle-Granger cointegration test could not be rejected, implying that the above markets are not cointegrated with DDEC. Moreover, by looking at the test results of Thambuttegama-Dambulla market pair, higher ADF values for the residual was observed only for tomatoes. Colombo- Dambulla market pair showed a higher ADF value for brinjals only. Dehiaththakandiya-DDEC pair also showed the same results in the long term. Therefore, all the above observations where market pairs had shown higher ADF values of the residuals, were not integrated with each other. Except the above few cases, the ADF statistics rejected the null hypothesis of no cointegration at 5\% significance level. Out of 36 market pairs, 28 were cointegrated and as a percentage that is $77 \%$. This implies that DDEC wholesale prices and wholesale prices of majority of the regional vegetable markets are cointegrated with each other pre-pandemic. 


\section{Results of error correction model}

Even though most of the markets are integrated in the long-run except in few cases, there may be disequilibrium in the short-run (Sidhu et al., 2010). Positioned on error correction terms, the adjustment of that disequilibrium to access the short-run equilibrium path was predicted in the study. The results from Vector Error Correlation Model (VECM), both coefficients and p values are presented in Table 4. The results revealed that for beans, carrots, tomatoes and brinjal, only three markets (Meegoda, Keppetipola and Galle) were cointegrated with DDEC in the short run. Only the Ampara regional market which is $195 \mathrm{~km}$ away from DDEC showed price disequilibrium in the short run for all the four vegetables.

Another VECM was carried out in order to identify the market integration peak periods in the preCOVID-19 period. Market integration peak periods and off-peak periods could be examined by running separate VECM models for a year for each vegetable. A year was divided into 4 periods as quarters. For Q1(January, Feb, March) none of the bean markets showed short run cointegrated behaviour in prices with DDEC. However, except Colombo and Meegoda, all the other markets showed cointegrated behaviour with DDEC

Table 3: Engle-Granger cointegration testing results (pre-COVID-19)

\begin{tabular}{lcccccccc}
\hline \multirow{2}{*}{$\begin{array}{l}\text { Regional } \\
\text { vegetable market }\end{array}$} & \multicolumn{2}{c}{ Beans } & \multicolumn{2}{c}{ Carrot } & \multicolumn{2}{c}{ Tomato } & \multicolumn{2}{c}{ Brinjal } \\
\cline { 2 - 9 } & $\begin{array}{c}\text { Test } \\
\text { Statistics }\end{array}$ & $\begin{array}{c}\mathrm{p} \\
\text { Value }\end{array}$ & $\begin{array}{c}\text { Test } \\
\text { Statistics }\end{array}$ & $\begin{array}{c}\mathrm{p} \\
\text { Value }\end{array}$ & $\begin{array}{c}\text { Test } \\
\text { Statistics }\end{array}$ & $\begin{array}{c}\mathrm{p} \\
\text { Value }\end{array}$ & $\begin{array}{c}\text { Test } \\
\text { Statistics }\end{array}$ & p Value \\
\hline Colombo & -4.27 & $0.001^{*}$ & -5.77 & $0.000^{*}$ & -5.58 & $0.000^{*}$ & -2.72 & 0.070 \\
Thambuttegama & -4.60 & $0.000^{*}$ & -5.20 & $0.000^{*}$ & -3.27 & $0.016^{*}$ & -3.60 & $0.006^{*}$ \\
Ampara & -2.68 & 0.077 & -2.72 & 0.071 & -2.48 & 0.121 & -4.91 & $0.000^{*}$ \\
Meegoda & -4.85 & $0.000^{*}$ & -4.34 & $0.000^{*}$ & -3.88 & $0.002^{*}$ & -4.08 & $0.001^{*}$ \\
Keppetipola & -1.75 & 0.408 & -3.05 & $0.031^{*}$ & -3.89 & $0.002^{*}$ & -4.56 & $0.000^{*}$ \\
Nuwara Eliya & -4.41 & $0.000^{*}$ & -4.53 & $0.000^{*}$ & -4.39 & $0.000^{*}$ & -5.19 & $0.000^{*}$ \\
Dehiaththakandiya & -3.55 & $0.007^{*}$ & -3.67 & $0.005^{*}$ & -4.21 & $0.001^{*}$ & -2.79 & 0.596 \\
Badulla & -3.65 & $0.005^{*}$ & -4.24 & $0.001^{*}$ & 3.94 & $0.002^{*}$ & -4.58 & $0.000^{*}$ \\
Galle & -3.53 & $0.007^{*}$ & -2.41 & 0.139 & -2.89 & $0.047^{*}$ & -2.07 & 0.082 \\
\hline
\end{tabular}

* Values followed by same letters in a column are not significantly different at $\mathrm{p}<0.05$

Table 4: Results of the Vector Error Correlation Model (VECM)

\begin{tabular}{lcccccccc}
\hline \multirow{2}{*}{$\begin{array}{l}\text { Regional } \\
\text { vegetable market }\end{array}$} & \multicolumn{2}{c}{ Beans } & \multicolumn{2}{c}{ Carrot } & \multicolumn{2}{c}{ Tomato } & \multicolumn{2}{c}{ Brinjal } \\
\cline { 2 - 9 } Colombo & Coef. & $\mathrm{p}$ Value & coef. & $\mathrm{p}$ Value & coef. & $\mathrm{p}$ Value & Coef. & $\mathrm{p}$ Value \\
\hline Thambuttegama & -0.35 & 0.0230 & -0.32 & $0.0430^{*}$ & -0.65 & $0.0000^{*}$ & 0.03 & 0.5940 \\
Ampara & -0.30 & $0.0000^{*}$ & -0.11 & 0.2430 & -0.18 & 0.3680 & 0.08 & 0.2430 \\
Meegoda & -0.01 & 0.0920 & -0.01 & 0.9020 & -0.06 & 0.2220 & 0.00 & 0.7970 \\
Keppetipola & -0.55 & $0.0010^{*}$ & -0.37 & $0.0070^{*}$ & -0.35 & $0.0300^{*}$ & -0.52 & $0.0000^{*}$ \\
Nuwara Eliya & -0.14 & $0.0000^{*}$ & -0.17 & $0.0010^{*}$ & -0.27 & $0.0000^{*}$ & -0.10 & $0.0090^{*}$ \\
Dehiaththakandiya & -0.21 & 0.0850 & -0.41 & $0.0010^{*}$ & -0.66 & $0.0000^{*}$ & -0.19 & 0.2260 \\
Badulla & -0.04 & $0.0466^{*}$ & -0.17 & $0.0080^{*}$ & -0.25 & $0.0000^{*}$ & -0.03 & 0.1970 \\
Galle & 0.04 & $0.0240^{*}$ & -0.16 & $0.0500^{*}$ & 0.00 & 0.9330 & -0.01 & 0.1420 \\
\hline & -0.51 & $0.0000^{*}$ & -0.34 & $0.0000^{*}$ & -0.62 & $0.0000^{*}$ & -0.30 & $0.0000^{*}$ \\
\hline
\end{tabular}

* Values followed by same letters in a column are not significantly different at $\mathrm{p}<0.05$ 
for carrots. Some tomato and brinjal markets also showed a similar behaviour of integration within first three months. But for the second quarter of the year analysed, none of the vegetable markets showed short run cointegration with DDEC prices. The similar behaviour could be observed in third quarter as well. However, in the last quarter again bean and carrot markets showed cointegrations with DDEC. This behaviour of prices could be observed in the pre-COVID-19 period.

The results of the above analyses show that the cointegration status before and during the Covid19 pandemic are different to each other. Figure 4 below shows the cointegration behaviour between DDEC and other regional market during the period of COVID-19 and before COVID-19 for both short run and long run. The coloured cells show the cointegration status in the long run and short run. Green coloured cells depict the cointegrated market pairs, while red coloured cells depict the non-cointegrated market pairs. Within those cells, the short run cointegration observations are marked as $S R$, while the long run cointegrations are marked as $L R$. Incidents where both long run and short run cointegrations are observed are marked as $L R, S R$. During the pandemic, few markets; Thambuttegama, Meegoda, Colombo, NuwaraEliya and Dehiaththakandiya, only for beans were cointegrated with DDEC. Nevertheless, before the pandemic, regional markets such as Meegoda, Thambuttegama, Keppetipola, Nuwara Eliya, Badulla, Galle showed long run or short run cointegration behaviour with DDEC for all the vegetables.

Figure 4: Long run and short run cointegration status of regional markets and DDEC in pre-COVID19 and during COVID-19 periods

\begin{tabular}{|c|c|c|c|c|c|}
\hline $\begin{array}{l}\text { Regional vegetable } \\
\text { market }\end{array}$ & Period & Beans & Carrot & Tomato & Brinjal \\
\hline \multirow{2}{*}{ Colombo } & Pre-COVID-19 & LR & LR,SR & LR,SR & \\
\hline & During COVID-19 & SR & & & \\
\hline \multirow{2}{*}{ Thambuttegama } & Pre-COVID-19 & LR,SR & LR & LR & LR \\
\hline & During COVID-19 & SR & & & \\
\hline \multirow{2}{*}{ Ampara } & Pre-COVID-19 & & & & LR \\
\hline & During COVID-19 & & & & \\
\hline \multirow{2}{*}{ Meegoda } & Pre-COVID-19 & LR, SR & LR,SR & LR,SR & LR,SR \\
\hline & During COVID-19 & SR & & & \\
\hline \multirow{2}{*}{ Keppetipola } & Pre-COVID-19 & SR & LR,SR & LR,SR & LR,SR \\
\hline & During COVID-19 & & & & \\
\hline \multirow{2}{*}{ Nuwara Eliya } & Pre-COVID-19 & LR & LR,SR & LR,SR & LR \\
\hline & During COVID-19 & SR & & & \\
\hline \multirow{2}{*}{ Dehiaththakandiya } & Pre-COVID-19 & LR,SR & LR,SR & LR,SR & \\
\hline & During COVID-19 & LR & & & \\
\hline \multirow{2}{*}{ Badulla } & Pre-COVID-19 & LR,SR & LR,SR & LR & LR \\
\hline & During COVID-19 & & & & \\
\hline \multirow{2}{*}{ Galle } & Pre-COVID-19 & LR,SR & SR & LR,SR & SR \\
\hline & During COVID-19 & & & & \\
\hline
\end{tabular}

Note: Green colour indicates cointegrated market pairs and red colour indicates market pairs which are not integrated with DDEC. Market pairs which show short run cointegration are indicated by "SR" and short run cointegration is indicated by "SR". 


\section{CONCLUSIONS}

Spatial market integration is examined by estimating price linkages among geographically separated beans, carrot, tomato, and brinjal markets with DDEC of Sri Lanka. Results revealed that in the pre-COVID-19 period (in 2018 and 2019), the regional vegetable markets except for Ampara, Dehiaththakandiya and Colombo, all the other markets were cointegrated with DDEC either long run or short run. Nevertheless, the

\section{REFERENCES}

Alexander, C., \& Wyeth, J. (1994). Cointegration and market integration: An application to the Indonesian rice market. The Journal of Development Studies, 30(2), 303-334.Bilgili, F. (1998). Stationarity and cointegration tests: Comparison of Engle-Granger and Johansen methodologies. Erciyes Üniversitesi İktisadi ve Idari Bilimler Fakültesi Dergisi, (13), 131-141.

De Silva, Y. Y. K., Rajapakshe, P. S. K., \& Amaralal, K. H. M. L. (2010). Price efficiency in tuna fish marketing in Sri Lanka-An application of cointegration approach. Sri Lanka Journal of Aquatic Sciences, 11.Dickey, D. A., \& Fuller, W. A. (1979). Distribution of the estimators for autoregressive time series with a unit root. Journal of the American Statistical Association, 74, 427-431.

Engle, R. F., \& Granger, C. W. (1987). Co-integration and error correction: representation, estimation, and testing. Econometrica: Journal of the Econometric Society, 251-276.

Faminow, M. D., \& Benson, B. L. (1990). Integration of spatial markets. American Journal of Agricultural Economics, 72(1), 49-62.Goletti, F., Ahmed, R., \& Farid, N. (1995). Structural determinants of market integration: The case of rice markets in Bangladesh. The Developing Economies, 33(2), 196-198.

Goodwin, B. K., \& Schroeder, T. C. (1991). Cointegration tests and spatial price linkages cointegration of regional markets with DDEC in the period of COVID-19 was comparatively weaker and the market pairs exhibited non-cointegration behaviours except for beans in Dehiaththakandiya, Nuwara Eliya, Thambuttegama, Meegoda, and Colombo. The results clearly indicate that even though the government imposed various protective measures to keep the vegetable supply chain resilient during the COVID-19 pandemic, the price transmission has not happened effectively between markets.

in regional cattle markets. American Journal of Agricultural Economics, 73(2), 452464.Hamilton, J.D., (1994). Time Series Analysis. Princeton University Press. Princeton, NJ, USA.

IPS. (2021). COVID-19 and Market Closure: Evidence from the Vegetable Sector in Sri Lanka. State of Economy 2021, Institute of Policy Studies of Sri Lanka. Colombo, Sri Lanka. 284-293

Jayasinghe-Mudalige, U. K. (2006). An economic analysis on spatial integration of regional rice markets in Sri Lanka. Sri Lankan Journal of Agricultural Economics, 8(1381-2016115723), 51-65.Perera, M, Kodithuwakku, S \& Weerahewa, J. (2011). Analysis of Vegetable Supply Chains of Supermarkets in Sri Lanka. Sri Lankan Journal of Agricultural Economics. 6. 10.4038/sjae.v6i1.3471.

Rajeevan, B. (2021). COVID-19 Impact on Sri Lanka Economics. Available at SSRN 3907451.

Sandaruwani, K. G. I. H., Kuruppu, I. V., \& Edirisinghe, J. C. (2018). Spatial linkages of green chili prices between a dedicated economic centre and other regional markets in Sri Lanka. Sri Lanka Journal of Food and Agriculture, 4(1).Thamiem, S., Perera, U., \& Weerahewa, J. (2010). Testing Market Integration of Sri Lankan Milk Market. Sri Lanka Journal of Humanities and Social Sciences, 1(2). 